\title{
A new species of the catfish genus Cordylancistrus (Siluriformes, Loricariidae) from the Sierra Nevada de Santa Marta, Colombia
}

\author{
FRANCISCO PROVENZANO R..$^{1,2}$, NADIA MILANI ${ }^{1} \&$ CARLOS ARDILA R. ${ }^{3}$ \\ ${ }^{1}$ Centro Museo de Biología, Instituto de Zoología y Ecología Tropical, Facultad de Ciencias, Universidad Central de Venezuela, Apar- \\ tado 47058, Caracas1041-A, Venezuela.E-mail: fprovenz@gmail.com/nadiamilani@gmail.com \\ ${ }^{2}$ Instituto de Ciencias Biológicas, Escuela Politécnica Nacional, Quito, Ecuador.E-mail: fprovenz@gmail.com \\ ${ }^{3}$ Universidad Metropolitana, Facultad de Medicina, Barranquilla, Departamento del Atlántico, Colombia. \\ E-mail: lebiasina@gmail.com
}

\begin{abstract}
As a part of an assessment of loricariid catfishes inhabiting the Andes of Colombia, specimens belonging to an interesting new species were identified. The new species is described herein, and it is tentatively included in the genus Cordylancistrus. The new species can be easily distinguished among its congeners by the presence of a unique diagnostic character: a fleshy keel or excrescence, black or dark brown, over the posterior tip of supraoccipital. Specimens of the new species were captured in rivers of the Sierra Nevada de Santa Marta and the Sierra de Perijá that drain to the Magdalena River Basin and Caribbean Sea. The occurrence of one species of Cordylancistrus in the Sierra Nevada de Santa Marta could have interesting biogeographic implications for hypotheses related to the geological history of northwestern corner of South America or to the dispersal or vicariance models used to explain biogeographical patterns of related species in Colombia.
\end{abstract}

Key words: Freshwaters fishes, taxonomy, diversity, Magdalena River Basin, Caribbean Sea Basin

\section{Resumen}

Como parte de una evaluación sobre los bagres loricáridos que habitan los Andes de Colombia, se identificaron ejemplares pertenecientes a una llamativa nueva especie. La nueva especie se describe aquí, y se incluye en el género Cordylancistrus, tentativamente. Se reconoce fácilmente entre sus congéneres por la presencia de un carácter diagnóstico único: una quilla o excrecencia carnosa, de color negro o marrón oscuro, sobre la punta posterior del supraoccipital. Los ejemplares de la nueva especie fueron capturados en ríos de la Sierra Nevada de Santa Marta y de la Sierra de Perijá que drenan a la cuenca del río Magdalena y al Mar Caribe. La presencia de una especie de Cordylancistrus en la Sierra Nevada de Santa Marta podría tener implicaciones biogeográficas interesantes para hipótesis relacionadas con la historia geológica de la esquina noroccidental de Sudamérica o con los modelos de dispersión o vicariancia utilizados para explicar los patrones biogeográficos de especies relacionadas en Colombia.

Palabras clave: Peces dulceacuícolas, Taxonomía, Diversidad, Cuenca del río Magdalena, Mar Caribe

\section{Introduction}

As part of a survey of loricariid catfishes inhabiting the Andes of Colombia, some museum lots of an interesting species were identified. All specimens came from piedmont rivers of the Sierra Nevada de Santa Marta, and Sierra de Perijá, Colombia, and represent a new species described herein. The new species is tentatively included in the genus Cordylancistrus, increasing number of Cordylancistrus species described for Colombia to three. The species C. platyrhynchus (Fowler, 1943) from the Amazon River basin, Colombia, was previously considered included in the genus Cordylancistrus (Provenzano \& Milani, 2006; Provenzano \& Villa-Navarro, 2017), but was transferred 
to the genus Chaetostoma (Armbruster, 2004, 2008), and we tentatively accept this move. According to known phylogenetic hypotheses, species grouped in the genera Andeancistrus, Chaetostoma, Cordylancistrus, Dolichancistrus, Leptoancistrus and Transancistrus constitute a monophyletic group, the Chaetostoma group or clade (Armbruster, 2004, 2008; Lujan, et al. 2015b,c). However, species traditionally included in Cordylancistrus do not appear to form a monophyletic group. Therefore, this genus is considered as questionable (Armbruster, 2004, 2008; Lujan, et al. 2015b). This result may be reflected in the variability of the external morphological characteristics of recently described new genera and species (Tan \& Armbruster, 2012; Salcedo, 2013; Salcedo \& Ortega, 2015; Lujan, et al. 2015a,c; Provenzano \& Villa-Navarro, 2017). Some of these new species exhibit external morphological characteristics such as a naked snout, lateral body plates with spiny keels, longest movable cheek odontodes pass pectoral-fin origin, etc., that may be present in species ascribed to different genera. This situation generates ambiguity about the precise generic allocation of species, and the identity of some genera. Therefore, a reevaluation of these characteristics is required to establish its appropriate applicability.

Ballen \& Vari (2012) carried out a revision of the genus Dolichancistrus, in which they identified two lots as Chaetostomus setosus Boulenger, 1887. This species was included in the genus Dolichancistrus by Isbrücker (2001), but Ballen \& Vari pointed out that D. setosus lacks the diagnostic features of that genus, and therefore considered the species as incertae sedis. The presence of "a supraoccipital dermal ridge" was reported for this species (Ballen \& Vari 2012: 503), although the original description of C. setosus does not mention the presence of such a ridge. These statements caught our attention and prompted the review of the type specimens of C. setosus, and the specimens used by Ballen \& Vari (2012).

The geographic distribution of the new species of Cordylancistrus described in this paper represents the second record from the Magdalena River Basin, and the first that inhabits rivers that drain to the Caribbean Sea. The distribution of species of Cordylancistrus in Colombia have interesting biogeographic implications, due to the insights they may provide regarding geologic processes that shaped the northwestern corner of South America.

\section{Materials and methods}

Specimens used in comparative analyses are listed in material examined. First segmented and unbranched ray of each fin is denominated spine. Measurements were made point to point with dial calipers to the nearest $0.1 \mathrm{~mm}$. Counts and measurements were made on the left side of specimens whenever possible. Standard length is expressed in $\mathrm{mm}$. All other measurements are expressed as percents of standard length. Measurements follow Boeseman (1968), Pérez \& Provenzano (1996) and Provenzano \& Milani (2006). Institutional abbreviations are as listed in Sabaj (2016).

\section{Cordylancistrus tayrona new species}

(Figure 1-2 Table 1)

\section{Dolichancistrus setosus Ballen \& Vari 2012}

Holotype. IAvHP 7506 (out MBUCV-V-27935), 78.4 mm SL, Colombia, Departamento Cesar, Magdalena River basin, Sierra Nevada de Santa Marta, Badillo River, tributary of Cesar River, north of Valledupar, approx. $10^{\circ} 12^{\prime} \mathrm{N}$, 6605’W, C. Ardila, 17 March 1997.

Paratypes. All from Colombia. Departamento Cesar, Magdalena River basin: MBUCV-V-27935, 4 ex (3 alcohol, 1 C\&S), 38.4-65.3 mm SL, Same data as the holotype. ICNMHN 3290, 4 ex., 40.4-42.8 mm SL, Quebrada Soria, Tuwy River, tributary of César River, near La Jagua de Ibirico, G. Galvis, 01 February 1996. ICNMHN 1158, 5 ex., 27.4-72.3 mm SL, west of the Serranía de Perijá, Mahuri river, tributary Cesar river, P. Cala, 13 November 1985. CIUA 698, 4 ex., 51.0-70.8 mm SL, Becerril, Cesar River system, Tucuy River, L. Ochoa, 26 March 2007. CAR 109, 1 ex., 49.2 mm SL, Sierra Nevada de Santa Marta, Seco River, tributary of César River, north of Valledupar, C. Ardila, 17 March 1997. CAR 110, 2 ex., 69.9-77.3 mm SL, Sierra de Perijá, Tocaimo River, tributary of César River, north of Agustín Codazzi, C. Ardila, 28 April 1997. CAR 113, 1 ex., 54.0 mm SL, Sierra Nevada de Santa Marta, Guatapurí River, tributary of César River, C. Ardila, 10 December 2002. MBUCV-V- 
26710, 6 ex (5 alcohol, 1 C\&S), 41.9-48.3 mm SL, Sierra Nevada de Santa Marta, Quebrada Los Clavos, tributary of César River, near Pueblo Bello, west of Valledupar, C. Ardila, October 1994. MBUCV-V-26711, 5 ex., 33.346.0 mm SL, Sierra Nevada de Santa Marta, Pontón River, tributary of César River, near Atanquez, C. Ardila, 23 September 1994. MBUCV-V-27910, 3 ex., 20.9-49.9 mm SL, Hurtado River, tributary of César River, R. Royero.

Departamento Magdalena, Caribbean Sea basin: ICNMHN 5750, 7 ex., 41.6-87.4 mm SL, Sierra Nevada de Santa Marta, Quebrada El Congo, tributary of Frio River, Y. López-Pinto, 01 February 2002.

Departamento La Guajira, Caribbean Sea basin: ICNMHN 6804, 6 ex., 60.0-96.0 mm SL, Corregimiento Distracción, Ranchería River, Chorreras, J. I. Mojica \& C. Castellanos, 01 January 2003. ICNMHN 8891, 9 ex., 49.0-62.7 mm SL, Corregimiento Distracción, Ranchería River, Chorreras El Cercado, J. I. Mojica \& C. Castellanos, 18 February 2004. ICNMHN 9775, 2 ex., 29.1-87.3 mm SL, Corregimiento Distracción, Ranchería River, Chorreras La Virgen, C. Castellanos, 04 December 2003. IAvHP 19, 5 ex., 29.8-138.8 mm LS, Ranchería

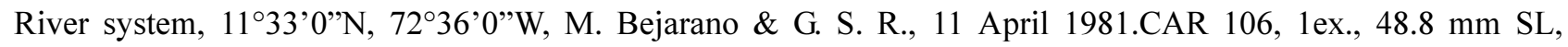
Ranchería River, Carlos Ardila, 27 April 1997. CZUT-IC-7279, 2 ex., 55.2-60.4 mm SL, Municipio de Dibulla, Jerez River, $300 \mathrm{~m}$ upstream the bridge on road to Riohacha, 28 September 2011.

Diagnosis. Cordylancistrus tayrona is distinguished from its congeners by the presence of a unique fleshy black or dark brown keel or excrescence over the posterior tip of supraoccipital. Furthermore, C. tayrona is distinguished from $C$. torbesensis by the presence of a strip of very small plates (granules) and odontodes along the snout border ( $v s$. border of the snout covered with plates, lacking odontodes). Additionally, C. tayrona can be distinguished from all other species grouped in Andeancistrus, Cordylancistrus, and Transancistrus, except from C. torbesensis and C. daguae, by the presence of elongated movable cheek odontodes, that reach the pectoral-fin origin ( $v s$. short movable cheek odontodes, that do not reach the pectoral-fin origin). Furthermore, C. tayrona is distinguished from all other species of Chaetostoma and Transancistrus, by the presence of odontodes on snout border (vs. snout border naked without odontodes), and from species of Leptoancistrus, by presence of adipose and anal fins (vs. adipose and anal fins absent). Cordylancistrus tayrona resembles the species of Dolichancistrus, but none of the species included in this genus have a fleshy keel on the posterior tip of supraoccipital. The new species lacks any movable cheek odontodes that reach or surpass the midpoint of the pectoral-fin spine length, neither the pectoral-fin spine reach or surpass the distal end of pelvic-fin spine as in Dolichancistrus species.

Description. Morphometric data are given in Table 1. Body slender, depressed anteriorly and slightly compressed posteriorly. Dorsal profile of body from tip of snout to dorsal-fin origin gently convex, straight and sloping downward from dorsal-fin origin to adipose-fin origin, and straight and horizontal to caudal-fin origin. Ventral profile of the body flat and straight. Head wide and depressed. Snout contour semicircular in dorsal view and covered with small plates. Narrow strip of granules (very small plates) present along anteroventral margin of snout. Odontodes over this strip of granules in different stages of development (Fig. 2), at sides larger odontodes are observed and at the center smaller ones. Nuptial males exhibit large odontodes (about as long as eye diameter) over the snout margin.

Nostrils juxtaposed and closer to the eyes than tip of snout. Anterior nostril easily visible but posterior is partially covered with skin flap. Eyes laterodorsal, dorsal edge of orbits flat. Small odontodes surround orbits. Interorbital space narrow and flat. Supraoccipital has an excrescence or fleshy keel, black or dark brown, at occiput that extends slightly posteriorly. In juveniles and some adults specimens, fleshy keel is covered by very thin and transparent layer of skin. Movable, hypertrophied cheek odontodes well developed, numbering 12 to 35 . Length of odontodes increase in size posteriorly, longest odontode surpasses the pectoral-fin origin independently of size of specimen (Fig. 2). No plates covering base of movable hypertrophied cheek odontodes anteriorly. Opercular bone with exposed surface conspicuos, with some enlarged odontodes on its distal margin.

Mouth wide and oval. Upper lip edge smooth, not crenulated. Lower lip border crenulated, and each crenulation with other minute undulations. Surface of lips papillose, papillae of anterior lip slightly larger. Maxillary barbels short and free. Upper and lower jaws wide and straight, parallel to each other. Teeth numerous and minute. More than 70 teeth in each premaxillae and dentary. Premaxillary teeth slightly larger than dentary teeth. Teeth villiform and asymmetrically bifid, medial cusp longer and wider than lateral cusp. Medial cusp rounded, lateral cusp pointed. Tooth apex curved toward interior of mouth. Tooth apex yellowish, stalk whitish. Without papillae posterior to premaxillaries and dentaries.

Ventral surface of head and belly naked. Lateral plates are visible posterior to anus, and cover ventral surface of body behind anal-fin. Anal-fin border undulated. Urogenital papillae visible in most specimens, small, located 
just posterior to the anus, sometimes covered by the anus and not visible. Urogenital papilla acuminate in males, and broad in females.

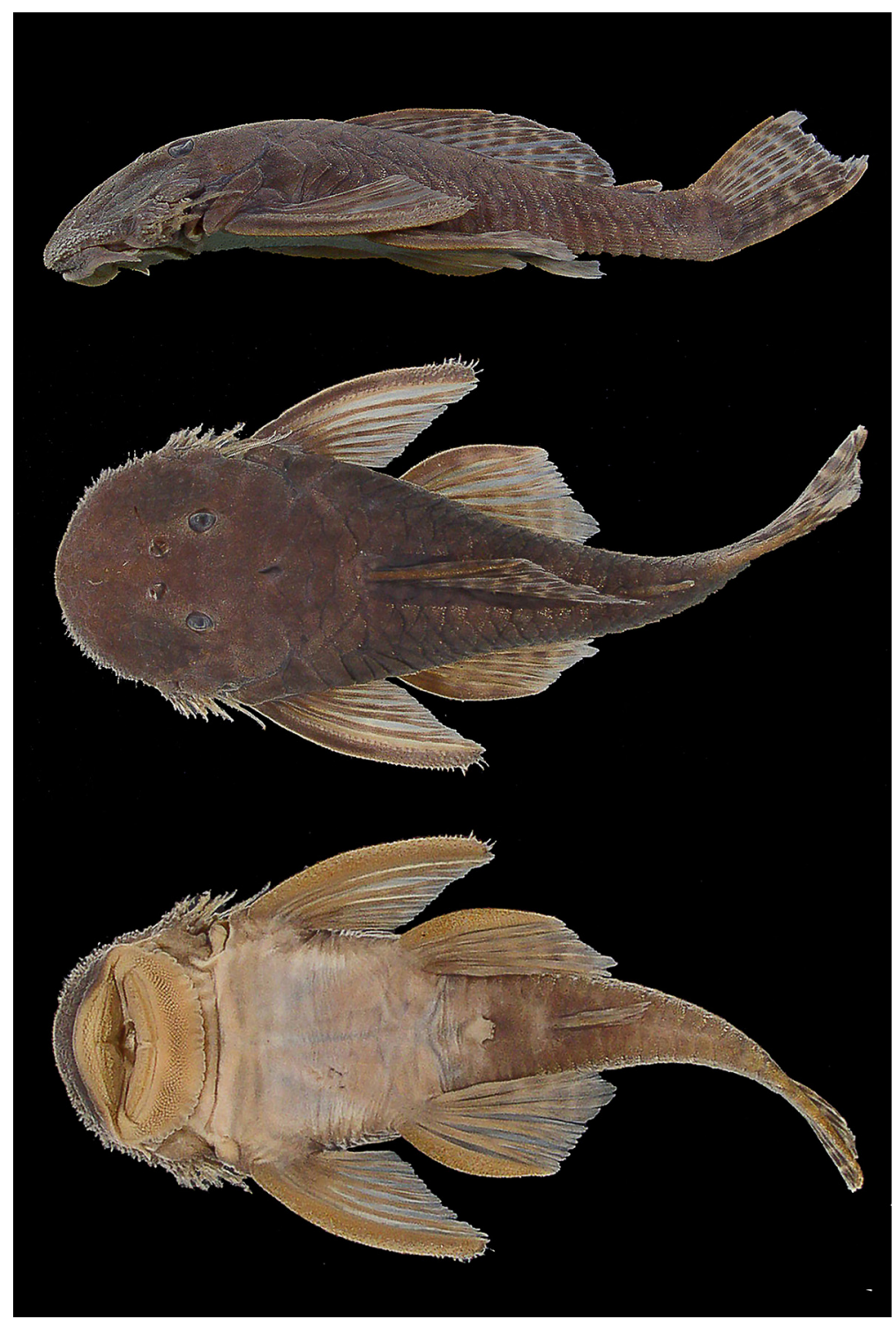

FIGURE 1. Cordylancistrus tayrona, IAvHP 7506, 78.4 mm SL. Holotype.

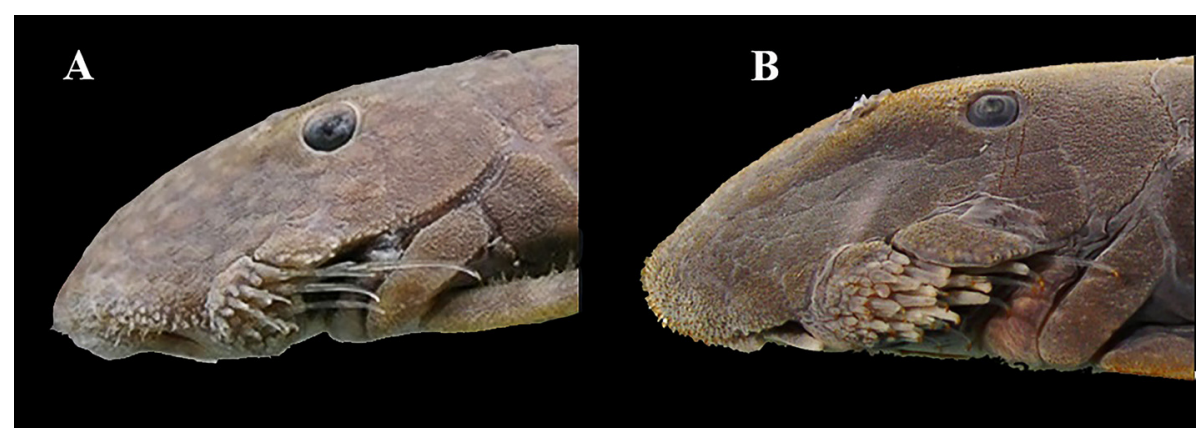

FIGURE 2. Lateral view detail of the head to show the length of movable cheek odontodes and the snout border with granulated band and odontodes. A) Cordylancistrus tayrona, MBUCV-V-27935, $65.3 \mathrm{~mm}$ SL, paratype. B) Cordylancistrus daguae, IMCN-1285, $88.3 \mathrm{~mm}$ SL.

Lateral line plates 23 to 24 . Post-anal plates 10 to 11 . Interdorsal plates six, no keeled plates between dorsal and adipose fins. Origin of dorsal fin anterior to pelvic fin origin. Dorsal-fin spinelet present, sometimes covered 
with tissue and difficult to see. Dorsal fin i,9 (rarely i,8), reaching adipose-fin origin when adpressed. Adipose fin well developed and always present. Adipose-fin spine straight. Pectoral fin i,6. Pectoral-fin spine almost reaching (in smaller specimens) or surpassing half pelvic-fin spine length when adpressed, and longer than longest branched ray. Dorsal and posterior edge of the pectoral-fin spine has one row of perpendicularly enlarged odontodes, better developed in larger specimens. Also in larger specimens, pectoral-fin branched rays with one to three rows of developed odontodes on dorsal surface proximally, most developed in nuptial males. Pelvic fin i,5. Its posterior margin nearly straight, reaching or almost reaching anal-fin origin when adpressed. Third and/or fourth branched pelvic-fin rays longest. Anal fin ii,3. Its posterior margin straight, second ray of anal fin longest. Caudal fin obliquely truncate; lower lobe longer than upper. Caudal fin rays i,14,i. Largest specimens about $115 \mathrm{~mm}$ total length, C. tayrona is an intermediately sized species within Cordylancistrus.

TABLE 1. Morphometric data of Cordylancistrus tayrona, expressed in $\%$ of standard length, $\mathrm{n}=24$.

\begin{tabular}{|c|c|c|c|c|c|}
\hline & Holotype & Average & STD & Min. & Max. \\
\hline SL & 78.4 & & & 33.0 & 87.4 \\
\hline Head length & 36.4 & 36.0 & 1.8 & 32.1 & 39.5 \\
\hline Predorsal length & 46.3 & 45.5 & 1.9 & 39.7 & 49.4 \\
\hline Postdorsal length & 30.2 & 30.1 & 1.7 & 26.9 & 33.8 \\
\hline Interdorsal length & 14.5 & 14.1 & 1.4 & 11.4 & 16.6 \\
\hline Preanal length & 68.2 & 70.5 & 1.2 & 67.9 & 73.0 \\
\hline Postanal length & 26.8 & 26.0 & 1.0 & 23.6 & 28.0 \\
\hline Thoracic length & 19.9 & 22.2 & 1.5 & 19.7 & 26.7 \\
\hline Abdominal length & 26.5 & 24.2 & 1.1 & 22.2 & 26.5 \\
\hline Dorsal fin base & 26.8 & 26.5 & 1.1 & 24.3 & 28.2 \\
\hline Dorsal spine length & 23.0 & 20.4 & 2.9 & 13.5 & 24.1 \\
\hline Pectoral spine length & 35.4 & 30.8 & 2.9 & 24.5 & 35.9 \\
\hline Pelvic spine length & 23.0 & 21.6 & 2.4 & 17.1 & 24.4 \\
\hline Cleithral width & 38.3 & 36.3 & 1.5 & 33.4 & 39.3 \\
\hline Caudal peduncle depth & 9.6 & 10.4 & 0.5 & 9.5 & 10.9 \\
\hline Head depth & 17.8 & 17.9 & 1.5 & 12.9 & 20.5 \\
\hline Snout length & 24.5 & 22.5 & 1.3 & 20.1 & 24.8 \\
\hline Interorbital width & 10.1 & 10.1 & 0.7 & 8.2 & 11.3 \\
\hline Orbital diameter & 4.6 & 5.2 & 0.7 & 3.6 & 6.7 \\
\hline Mandibular ramus length & 10.5 & 10.5 & 1.5 & 7.3 & 15.3 \\
\hline
\end{tabular}

Color. Specimens preserved in 70\% ethanol show variation of color pattern associated with localities and size. Most common color pattern of the head and dorsolateral surface of the body is overall brown to dark brown with faded whitish spots. Specimens from Ranchería River greenish or pale brown with conspicuos cream spots. In some specimens from Ranchería River, faded spots on sides of head arranged in three or four irregular bands, from near anterior border of snout. In all specimens, abdominal surface is uniformly creamy or whitish. Dorsal-fin spine and branched rays with four to five dark bands, interradial membrane hyaline, except for black spot between bases of spine and first branched ray. Pectoral-fin spine with six to seven dark bands, and branched rays with two to five dark bands. Pelvic-fin spine with four dark bands, and branched rays with two to four dark bands. Interradial membrane of pectoral and pelvic fins hyaline. Anal-fin whitish. Adipose-fin with whitish vertical band. Caudal-fin rays with four to six dark bars or bands, interradial membranes hyaline.

Geographical distribution. Northeastern Colombia, drainages around the Sierra Nevada de Santa Marta and western slope of the Sierra de Perijá, Cesar River system (Magdalena River Basin), Frio River and Ranchería River (Caribbean Sea) Fig. 3. Additionally, two more localities were found. One locality corresponds to the north of Departamento de Bolivar, Colombia, photos of specimens from this locality were identified, but specimens were 
not secured nor cataloged. Thus, the locality is considered questionable, but probable. The second locality is Socuy River, Maracaibo Lake Basin, Venezuela. These specimens are cataloged, MBUCV-V-35667, and were donated by a person dedicated to ornamental fish trading, without additional data. Freshwater environments of the Maracaibo Lake Basin are some of the best sampled areas in Venezuela, especially the north region of the basin. Since Schultz (1944) to date no specimens of this species have been collected. These considerations suggest that the occurrence of $C$. tayrona in the Maracaibo Lake Basin is questionable.

Habitat. Specimens of C. tayrona were collected in piedmont rivers associated with humid tropical areas of the Sierra Nevada de Santa Marta. These rivers have transparent waters, strong to moderate current and temperatures ranging $18-24^{\circ} \mathrm{C}$. River substrate materials include rocks, small stones and sand. Aquatic vegetation is scarce or absent, because forest canopy shades most of the river course.

Etymology. The species name, "tayrona", refers to the Tayrona culture or Tayrona nation, an indigenous group that occupied the area of the Sierra Nevada de Santa Marta, and more broadly the area of northeastern Colombia. The name of the species is a homage to these brave and clever people and to their descendants who today live restricted in the Sierra Nevada de Santa Marta. The species name is treated as a noun in apposition.

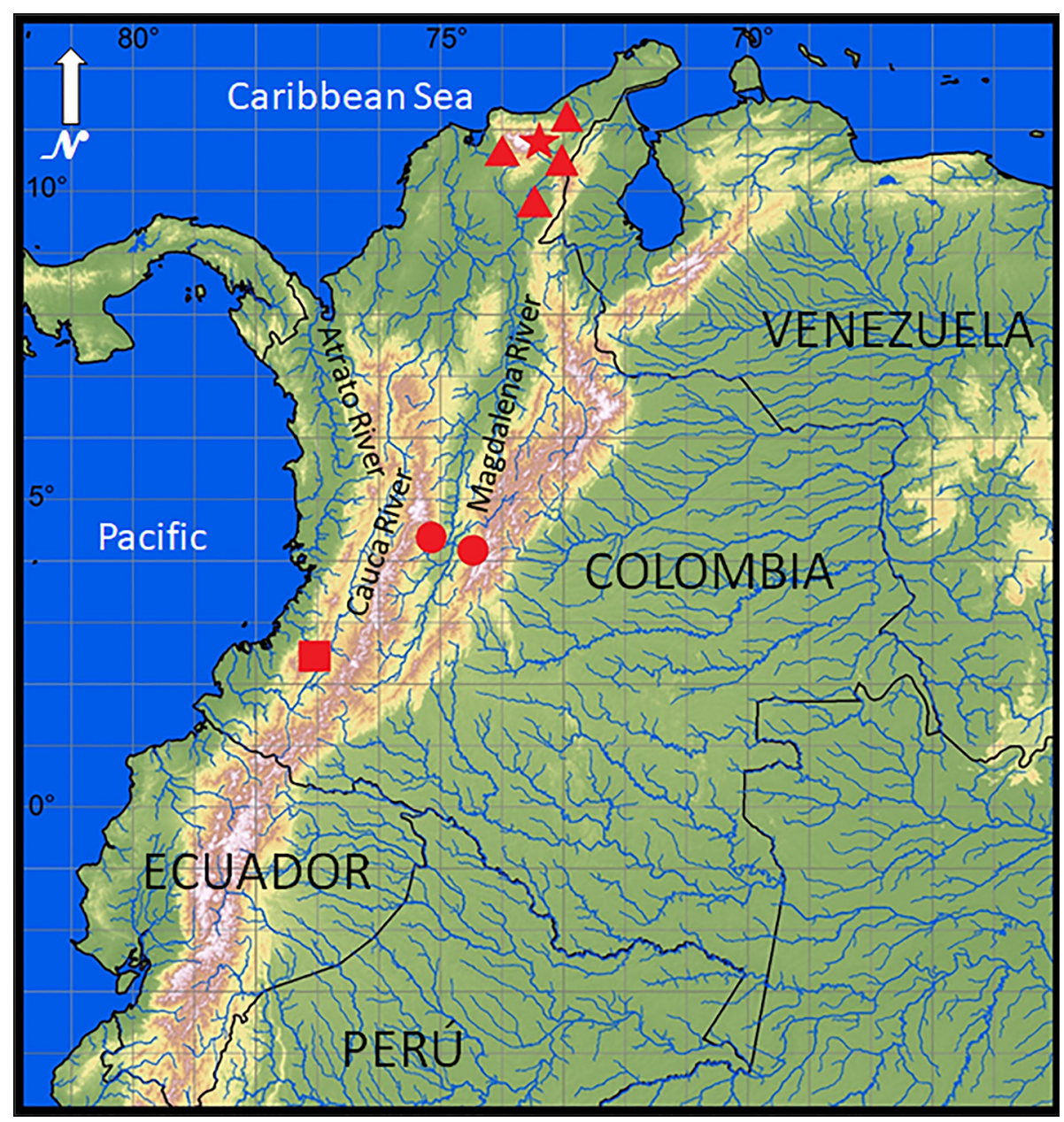

FIGURE 3. Geographic distribution of Cordylancistrus species in Colombia. Cordylancistrus tayrona (triangles, star type locality), Cordylancistrus daguae (square), Cordylancistrus pijao (circles), each symbol may represent more than one lot.

\section{Comparison between Chaetostoma setosus Boulenger, 1887 and Dolichancistrus setosus Ballen \& Vari, 2012.}

Boulenger (1887) described Chaetostomus setosus from the Andes of Colombia, without giving a precise locality, and, in the original description, there is no mention of a fleshy keel or excrescence on the posterior end of the supraoccipital. Examination of the types of $C$. setosus confirm absence of the fleshy keel. Additionally, C. setosus has an elongated pectoral-fin spine, which reaches the posterior border of pelvic-fin, at least in males. 
Ballen \& Vari (2012) reviewed the species of the genus Dolichancistrus. They analyzed two lots that they identified as Dolichancistrus setosus (Boulenger, 1887). Among other external characters, they pointed out that these specimens have a fleshy keel on the supraoccipital. According to our observations these specimens clearly represent a different species from C. setosus of Boulenger. We examined CIUA 698 and ICNMHN 1158 used by Ballen \& Vari (2012), and we have confirmed that these specimens belong to C. tayrona n. sp. and not to C. setosus Boulenger, 1887.

\section{Discussion}

Specimens of Cordylancistrus tayrona have some external characters that establish unambiguously its inclusion in the Chaetostoma group or clade, formally proposed by Armbruster (2008) and reaffirmed by Lujan, et al. (2015b). Specimens of $C$. tayrona have eight or more dorsal-fin branched rays, premaxillary and dentary straight and horizontally oriented, very wide, ramus length equal to or greater than interorbital distance, more than 50 teeth in each ramus, flat supraoccipital, and a naked abdomen.

The placement of the new species in Cordylancistrus is based on a combination of absence/presence of characters, more than on the presence of exclusive characters. As has happened in recent descriptions of species belonging the Chaetostoma group, the recognition of $C$. tayrona exemplifies the variability of some external morphological characteristics whose taxonomic value requires reevaluation. The new species possesses a series of characters that can be found among species placed in other genera of the Chaetostoma group. Starting with the diagnostic character of the species among congeners, the presence of a fleshy keel on posterior tip of supraoccipital. This character is present in some species of Chaetostoma (Rapp Py-Daniel, 1991; Ceas \& Page, 1996; Lasso \& Provenzano, 1997; Ballen, 2011; Ballen, et al. 2016). However, the new species is not included in Chaetostoma because other external characteristics (see below) that are traditionally used to recognize species of this genus match partially or not at all.

Mobile cheek odontodes, in C. tayrona, are elongated with the longest reaching or exceeding origin of the pectoral fin. Outside of Cordylancistrus, a similar condition of this character is found in species of Dolichancistrus and Leptoancistrus, but in those species the one or two longest movable cheek odontodes reach the middle or extend beyond the pectoral-fin spine. Unlike the species of Leptoancistrus, C. tayrona has both adipose and anal fins (Meek \& Hildebrand, 1916; Dahl, 1964). Additionally, in species of Dolichancistrus the pectoral-fin spine of males are greatly elongated such that the tip is near or passes beyond the posterior end of the pelvic-fin spine (Isbrücker, 1980; Ballen \& Vari, 2012). The pectoral-fin spine of the new species, usually reaches or slightly passes halfway along the pelvic-fin spine length. In species of Transancistrus and Andeancistrus the movable cheek odontodes do not reach the pectoral-fin base. Movable cheek odontodes of $C$. tayrona seem to be similar to those present in some species of Chaetostoma (Lujan, et al. 2015c: type 4), but other external characters do not match between them, such as a naked area of the snout, the border of the snout with plates, and absence of odontodes on the snout border. Specimens of C. tayrona have a tiny granulated strip at the snout border, where odontodes are present (Fig. 2). Inside the Chaetostoma group, this character is reported also for species of Dolichancistrus (Ballen \& Vari, 2012). Species included in Transancistrus have a naked snout border, and species of Chaetostoma have a larger naked surface, mainly towards the dorsoanterior region of snout, in all species of these two genera there is no mention or report of the presence of any kind of odontodes, on naked areas of snout (Rapp Py-Daniel, 1991; Ceas \& Page, 1996; Lasso \& Provenzano, 1997; Salcedo, 2003, 2006a,b, 2013; Ballen, 2011; Tan \& Armbruster, 2012; Salcedo \& Ortega, 2015; Lujan, et al. 2015c; Ballen, et al. 2016). Species of Andeancistrus have a snout totally covered with plates, but lack enlarged odontodes, and A. platycephalus has keels on lateral body plates (Lujan, et al. 2015a). The analyzed external characters, seem to indicate that the new species is closer to species allocated in the genus Cordylancistrus. An analysis of the osteology is ongoing to provide data intended to clarify overlaps and ambiguities of some external characteristics between species included in the Chaetostoma group. The analysis performed between C. setosus Boulenger, 1887, D. setosus (of Ballen \& Vari, 2012), and C. tayrona establishes: Chaetostomus setosus Boulenger, 1887 is a valid species and different from C. tayrona. The generic allocation of $C$. setosus Boulenger, 1887 requires further analysis and new specimens, meanwhile, it is suggested to retain the species as Dolichancistrus. Some of the specimens used by Ballen \& Vari (2012) were misidentified as D. setosus, and these correspond to specimens of C. tayrona. 
Hemiancistrus platyrhynchus Fowler, 1943 was described from Colombia, Florencia, Caquetá River system, Amazon River Basin. The species was included in the genus Cordylancistrus by Isbrücker (2001) and subsequently transferred to the genus Chaetostoma (Armbruster 2004). In previous articles (Provenzano \& Milani 2006; Provenzano \& Villa-Navarro 2017), the species was included in Cordylancistrus, but the comparative analysis of external morphology shows the presence of very small, inconspicuous, and scarcely movable cheek odontodes, in this species. This character seems to indicate that its generic allocation need to be evaluated. An osteological comparison is currently being carried out (FP) in order to obtain data to clarify the generic status of this species. Meantime, the species is considered grouped in genus Chaetostoma.

Among species included in Cordylancistrus, the fleshy keel at the posterior tip of supraoccipital, allows recognition unequivocally of $C$. tayrona. In addition, the length of the movable cheek odontodes separate this species from C. perijae, C. nephelion and C. pijao. (Pérez \& Provenzano, 1996; Provenzano \& Milani, 2006; Provenzano \& Villa-Navarro, 2017), and the presence of odontodes on the border of the snout facilitate its recognition from C. torbesensis, $C$. perijae, $C$. nephelion and $C$. pijao. Only $C$. daguae shows odontodes on the snout border (Fig. 2). Analyzing the Colombian species of Cordylancistrus, it is observed that C. pijao shows a more robust and deep body, whereas $C$. daguae and $C$. tayrona are less robust and deep. Likewise, the pattern of the movable cheek odontodes is more similar between C. daguae and C. tayrona. Cordylancistrus pijao shows more similarity to that observed in C. perijae and C. nephelion. The snout border seems to indicate a greater affinity between $C$. daguae and $C$. tayrona. These external morphological characteristics might suggest a closer relationship between $C$. daguae and C. tayrona, than any of them with C. pijao.

The Sierra Nevada de Santa Marta is the most prominent mountain system of northern Colombia. They are the highest mountains in the country, and their origin and evolution is very complex (Tschanz et al. 1974). It has been suggested that its origins were related to collision of the Nazca, South America and Caribbean plates, and has an estimated age of Campanian, circa 72 Mya (Villamil, 1999). Also, for a long period of time the Sierra Nevada de Santa Marta was connected with the Central Cordillera (Villamil 1999). Apart from this interesting geological history, the geographical distribution of the three species of Cordylancistrus from Colombia is disjunct. If we consider that the external morphology of C. tayrona and C. daguae is more similar, we could propose that at least two fragmentation events must have occurred. First event: raising the Cordillera Occidental isolated the ancestor of C. pijao from the rest of a hypothetical population with a wide distribution in Colombia. Second event: C. tayrona and $C$. daguae may share a common ancestor that had a wide distribution in the Western region of Colombia (north and central), and probably, this distribution was fragmented by subsequent events of Andean orogenesis and the species that we observe today evolved in those localities. Phylogenetic analyses are necessary to know species relationship and test these hypotheses.

\section{Acknowledgements}

This work was partially supported by the All Catfish Species Inventory project funded by the U.S.A. National Science Foundation (DEB-0315963) granted to FPR. Thanks to Norma Salcedo, John G. Lundberg, Nathan Lujan and Jonathan Armbruster for a critical review and comments of the manuscript. We are indebted to numerous people for help when visiting museums, our deep gratitude to the following institutions: Colección de Peces del Museo de Biología de la Universidad Central de Venezuela, Caracas, Venezuela. Colección de Peces, Universidad de Tolima, Colombia. Colección de Peces, Instituto Alexander von Humboldt, Villa de Leyva, Colombia. Colección de Peces, Instituto de Ciencias Naturales, Universidad Nacional, Bogotá, Colombia. Colección de Peces, Instituto de Biología, Universidad de Antioquia, Medellín, Colombia, INCIVA, Cali, Colombia. Field Museum of Natural History, Chicago, USA. Academy of Natural Science, Philadelphia, USA. Bristish Museum of Natural History, London, UK, Colección de Peces del Museo de la Escuela Politécnica Nacional, Quito, Ecuador. To Barry Chernoff, Scott A. Schaefer, Richard P. Vari, Oliver Crime, Germán Galvis, José Iván Mojica, Saulo Usma, Javier Maldonado, Francisco Villa, Armando Ortega-Lara, Saúl Prada, Yesid López Pinto, Carlos Lasso, Luz Fernanda Jiménez, Henry Agudelo, Carlos DoNascimiento, Ramiro Barriga-Salazar, Alberto Marcano and Vladimir Carvajal. 


\section{Material examined}

Andeancistrus eschwartzae: MEPN-11196, 15 ex., 82.2-141.5 mm SL, Ecuador, Morona Santiago Province, Río Amundal afluente del río Palora, approx. 01 44'45”S $78^{\circ} 02^{\prime} 58^{\prime \prime} \mathrm{W}, \mathrm{N}$. Lujan, D. Taphorn \& R. Barriga, 08 September 2012.

Andeancistrus platycephalus: ANSP-153645, 2 ex., 86.6-115.4 mm SL, Ecuador, Chiguaza River, Cutucu mountain, elevation 1075 m, R. M. Peck, 18 June 1984. FMNH-97429, 1 ex., 90.1 mm SL, Ecuador, ZamoraChinchipe, Zamora River system, Quebrada Tunantza, approx. $04^{\circ} 00^{\prime} 30^{\prime \prime} \mathrm{S} 78^{\circ} 53^{\prime} 05^{\prime \prime} \mathrm{W}, \mathrm{R}$. Barriga, M. Ibarra \& Lema, 15 March 1979. MEPN-11418, 6 ex., 75.4-96.5 mm SL, Ecuador, Morona Santiago Province, Río Yungantza near Limón community, approx. 02 58’27'S 78²6’49”W, D. Taphorn, N. Lujan \& R. Barriga, 04 September 2012. MEPN-18597, 3 ex., 109.8-133.5 mm SL, Ecuador, Zamora Province, Rio Blanco, in front house of Andrade family, approx. 03 $48^{\prime} 04^{\prime \prime}$ S 78 $33^{\circ} 59^{\prime \prime}$ W, R. Barriga, J. Sharupe \& J. Sandoval, 07 October 2008.

Chaetostoma anomalum: MBUCV-V-33279, 9 ex., 60.3-140.8 mm SL, Venezuela, Mérida State, Maracaibo Lake Basin, Chama River system, Quebrada El Peñon frente a la ciudad de Mérida, approx. $08^{\circ} 35^{\prime} \mathrm{N} 71^{\circ} 08^{\prime} \mathrm{W}, \mathrm{S}$. Schaefer, F. Provenzano \& A. Marcano, 26 October 2006.

Chaetostoma guairense: MBUCV-V-21802, 6 ex., 58.9-84.2 mm SL, Venezuela, Miranda, Caribbean Sea Basin, Tuy River system, Mesia River, near Corocito, approx. $10^{\circ} 12^{\prime} \mathrm{N} 66^{\circ} 05^{\prime} \mathrm{W}$, N. Padilla \& H. Camejo, 26 January 1992.

Chaetostoma platyrhynchus: MBUCV-V-32672, 4 ex., 48.8-67.7 mm SL, Colombia, Putumayo, Mocoa, Sangoyaco River, J. Maldonado, 06 March 2005. IAvH 5252, 1 ex., 74.0 mm SL, Colombia, Putumayo, Mocoa River, Finca La Cascada, J. Maldonado, 07 March 2005.

Chaetostoma vasquezii: MBUCV-V-27940, Paratype, $149.0 \mathrm{~mm}$ SL, Venezuela, Bolivar State, Orinoco River Basin, Caura River system, raudales del caño El Cambur, V. Ponte, G. Colonnello \& M. Curvelo, 5 February 1991. Chaetostoma venezuelae: MBUCV-V-9762, 4 ex., 58.6-81.1 mm SL, Venezuela, Monagas State, Atlantic Basin, San Juan River system, Río Caripe, sector Vallesolo, 6 km de Caripito, A. Machado \& L. Aguana, 28 April 1977.

Chaetostomus platycephalus: BMNH-1898.11.4.42, Holotype, $110.3 \mathrm{~mm} \mathrm{SL}$, Ecuador (eastern), Bomboiza River, upper Amazon River basin.

Chaetostomus setosus: BMNH-1880.2.26.9-10, Holotype \& Paratype, 79.2-95.2 mm LS, Colombia.

Cordylancistrus daguae: IMCN-1285, 3 ex., 66.0-88.3 mm SL, Colombia, Departamento del Valle, Aguaclara River, near the confluence with Anchicayá River, A. Ortega-Lara, 14 July 2002.

Cordylancistrus nephelion: MBUCV-V-21800, Holotype, $129.1 \mathrm{~mm}$ SL, Venezuela, Miranda State, Caribbean Sea basin, Tuy River system, Mesia River, tributary of the Guare River, near Village Corocito, approx. $10^{\circ} 10^{\prime} \mathrm{N}$ $67^{\circ} 05^{\prime} \mathrm{W}$, N. Padilla \& H. Camejo, 26 January 1992. MBUCV-V-27872, Paratype, $61.0 \mathrm{~mm}$ SL; Venezuela, Caribbean Sea basin, Miranda State, Tuy River system, Mesia River, near El Salado, approx. $10^{\circ} 12^{\prime} \mathrm{N} 67^{\circ} 03^{\prime} \mathrm{W}, \mathrm{N}$. Padilla \& H. Camejo, 29 May 1994.

Cordylancistrus perijae: MBUCV-V-21747, 7 Paratypes, 32.4-121.3 mm SL, Venezuela, Zulia state, Maracaibo Basin, Sierra de Perijá, Caño Colorado, tributary to the Palmar River, 100 meters from the dam site (under construction), approx. $10^{\circ} 37^{\prime} 12^{\prime \prime} \mathrm{N} 72^{\circ} 25^{\prime} 34^{\prime}$ 'W, elevation $150 \mathrm{~m}$, C. Casler, J. Toledo \& W. Villalobos, 11 July 1989.

Cordylancistrus pijao: MBUCV-V-32974, Paratype, $117.6 \mathrm{~mm}$ SL, Colombia, Departamento de Tolima, Municipio Villarrica, Vereda La Arcadia, Magdalena River basin, Prado River system, Quebrada Aguas Blancas at

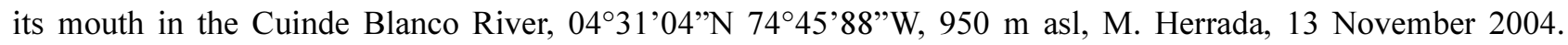
MBUCV-V-35677, Paratype, $122.8 \mathrm{~mm}$ SL, Municipio San Antonio, Vereda Florida Baja, Saldaña River system, Cucuana River, Y. López Pinto, 20 July 2008. MBUCV-V-35678, Paratype, $147.5 \mathrm{~mm}$ SL, Municipio Roncesvalles, Vereda Pringamosal, Saldaña River system, Cucuana River, under the hanging bridge, $04^{\circ} 01$ '33.1”N 75²8'17.1’W, Y. López Pinto, 01 June 2008.

Cordylancistrus santarosensis MECN-DP-2061, Holotype, $70.8 \mathrm{~mm} \mathrm{SL}$, Ecuador, El Oro Province, Santa Rosa River, Limón, Playas, approx. 03³4'10”S 7956’34.5”W, W. Aguirre, 09 July 2008.

Cordylancistrus torbesensis MBUCV-V-29430 (ex. MCNG-8066), 1 ex., $57.4 \mathrm{~mm}$ SL, Venezuela, Táchira

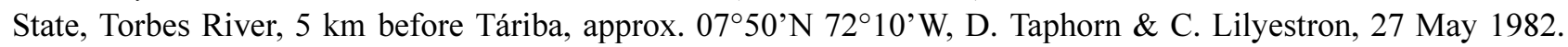
MBUCV-V-29432 (ex. MCNG-43287), 5 ex., 27.9-67.9 mm SL, Venezuela, Táchira State, Quinimari River, before confluence into Torbes River, approx. $07^{\circ} 37^{\prime} \mathrm{N} 72^{\circ} 10^{\prime} \mathrm{W}$, S. Usma \& L. Vasquez, 02 November 1999. 
Dolichancistrus carnegiei: MBUCV-V-27286, 10 ex., 62.4-102.8 mm SL, Colombia, Departamento de Santander, Hato River, Pie de Cuesta, Carlos Ardila, 04 May 1991.

Dolichancistrus fuesslii: MBUCV-V-35772 (ex. MHN-UPTC-PE-053), 8 ex., 66.5-115.7 mm SL, Colombia, Departamento de Boyaca, Municipio Jenesano, Río Jenesano, J. Andrade, J. Arias \& Delgado Paz Paez, 05 February 2006

Hemiancistrus daguae: FMNH-56052, Holotype, 60.4 mm SL, Colombia, Caldas. FMNH-56053, 3 Paratypes, 32.3-75.8 mm SL, Colombia, Caldas. FMNH-56054, 2 Paratypes, 33.6-65.9 mm SL, Colombia, Caldas.

Hemiancistrus platyrhynchus: ANSP-70512, Holotype, $70.7 \mathrm{~mm}$ SL, Colombia, Florencia, Orteguasa River basin, Brother Nicéforo María, 1931. ANSP-70513, Paratype, 67.75 mm SL, Colombia, Florencia, Orteguasa River basin, Brother Nicéforo María, 1931. MBUCV-V-18376 (ex. ANSP-84570), 3 ex., 37.4-56.1 mm SL, Colombia, Brother Nicéforo María, 1931.

Leptoancistrus canensis: MBUCV-V-28064 (ex. STRI-4851), 6 ex., 27.0-37.9 mm SL, Panamá, Quebrada Bayano, aprox. 0907’12”N 78²1’36”W, 14 February 1996.

Pseudancistrus atratoenesis: ICNMHN-46, 7 Paratypes (5 Alc, 2 C\&S), 42.81-75.50 mm SL, Colombia, Departmento de Antioquiá, Quebrada La Noche, tributary to upper Río Atrato, Rio Sucio, western Colombia, elevation about 550 meters. 10 August 1959.

Pseudancistrus carnegiei: FMNH-58350, Holotype, 82.67 mm SL, Colombia, Santander, Río San Gil. FMNH58351, 2 of 5 Paratypes, 17.1-31.42 mm SL.

Pseudancistrus cobrensis: MBUCV-V-18375 (ex. USNM-121037), 10 Paratypes, 12.7-53.8 mm SL, Venezuela, Táchira State, Maracaibo Basin, Catatumbo River system, Cobre River, below La Grita, tributary to Quinta River, approx. 0802`N 7159’W, L.P. Schultz, 31 March 1942.

Pseudancistrus pediculatus: FMNH-58352, Holotype, $84.10 \mathrm{~mm}$ SL, Colombia, Villavicencio, Río Negro. FMNH-58564, 2 of 3 Paratypes, 34.46-63.12 mm SL. FMNH-58565, 2 of 4 Paratypes, 32.04-69.9 mm SL.

Pseudancistrus torbesensis: MBUCV-V-18374 (ex. USNM-121002), 5 Paratypes, 23.8-51.8 mm SL, Venezuela, Táchira State, Orinoco Basin, Apure River system, Torbes River, 1 kilometer above Táriba, tributary to Uribante River, approx. 0750’N 72²0’W, L.P. Schultz, 31 March 1942.

Transancistrus aequinoctiale: MEPN-8805, 3 ex., 79.1-84.1 mm SL, Ecuador, Imbabura Province, Aguas Claras, Altos del Río Guayllabamba, approx. $00^{\circ} 14^{\prime} 05^{\prime}{ }^{\prime}$ 78 48'50”W, M. Olalla, Sep. 1961. MEPN-18600, 3 ex., 83.4-112.7 mm SL, Ecuador, Pichincha Province, Río Pachijal afluente del Guayllabamba, approx. $00^{\circ} 01$ '10"N $78^{\circ} 47^{\prime} 12^{\prime}$ W, M. Olalla, August 1969.

Transancistrus santarosensis: MEPN-11220, 4 ex., 26.3-52.0 mm SL, Ecuador, El Oro Province, Santa Rosa River, near Bado, approx. 03³3’31'S 7956'48”W, N. Lujan, D. Taphorn \& R. Barriga, 29 August 2012. MBUCV-V-35694, 4 ex., 62.5-94.6 mm SL, Ecuador, Bolívar Province, Guayas River basin, Vinces River system, Caluma river, near Guaranda, without additional data.

\section{Literature cited}

Armbruster, J.W. (2004) Phylogenetic relationships of the suckermouth armored catfishes (Loricariidae) with emphasis on the Hypostominae and Ancistrinae. Zoological Journal of the Linnaean Society, 141, 1-80. https://doi.org/10.1111/j.1096-3642.2004.00109.x

Armbruster, J.W. (2008) The genus Peckoltia with the description of two new species and a reanalysis of the phylogeny of the genera of the Hypostominae (Siluriformes, Loricariidae). Zootaxa, 1822, 1-76.

Ballen, G. A. (2011) A new species of Chaetostoma Tschudi (Siluriformes: Loricariidae) from Colombia with a definition of the $C$. anale species group. Papéis Avulsos de Zoologia, 51 (26), 383-398.

Ballen, G.A. \& Vari, R.P. (2012) Review of the Andean armored catfishes of the genus Dolichancistrus Isbrücker (Siluriformes: Loricariidae). Neotropical Ichthyology, 10 (3), 499-518. https://doi.org/10.1590/s1679-62252012000300003

Ballen, G.A., Urbano-Bonilla, A. \& Maldonado-Ocampo, J.A. (2016) Description of a new species of the genus Chaetostoma from the Orinoco River drainage with comments on Chaetostoma milesi Fowler, 1941 (Siluriformes: Loricariidae). Zootaxa, 4105 (2), 181-197. https://doi.org/10.11646/zootaxa.4105.2.6

Boeseman, M. (1968) The genus Hypostomus Lacépède, 1803, and its Surinam representatives (Siluriformes, Loricariidae). Zoologische Verhandelingen, 99, 1-89, pls. 1-18.

Boulenger, G.A. (1887) On new siluroid fishes from the Andes of Columbia. Annals and Magazine of Natural History, Series 5, 19 (113), 348-350.

https://doi.org/10.1080/00222938709460255 
Ceas, P.A. \& Page, L.M. (1996) Chaetostoma yurubiense (Teleostei: Siluriformes), a new species of loricariid catfish from the Aroa, Urama, and Yaracuy River systems in Venezuela. Copeia, 3, 671-677. https://doi.org/10.2307/1447531

Dahl, G. (1964) La ictiofauna del río San Jorge. In: Dahl, G., Medem, F. \& Ramos Henao, A. (Eds.), El Bocachico, contribución al estudio de su biología y de su ambiente. Departamento de Pesca de la Corporación Autónoma Regional de los Valles del Magdalena y del Sinú, C.V.M. Talleres Gráficos Banco de la República de Colombia, Bogotá, pp. 1-144.

Fowler, H. (1943) A collection of fresh-water fishes from Colombia, obtained chiefly by Brother Nicéforo Maria. Proceedings of the Academy of Natural Sciences of Philadelphia, 95, 223-266.

Isbrücker, I.J.H. (1980) Classification and catalogue of the mailed Loricariidae (Pisces, Siluriformes). Verslagen en Technische Gegevens, Instituut voor Taxonomische Zoölogie, Universiteit van Amsterdam, 22, 1-181.

Isbrücker, I.J.H. (2001) Nomenklator der Gattungen und Arten der Harnischwelse, Familie Loricariidae Rafinesque, 1815 (Teleostei, Ostariophysi). Datz Harnischwelse, 2, 25-53

Lasso, C.A. \& Provenzano, F. (1997) Chaetostoma vasquezi, nueva especie de corroncho del escudo de Guayana, Estado Bolívar, Venezuela (Siluroidei: Loricariidae): Descripción y consideraciones biogeográficas. Memoria de la Sociedad de Ciencias Naturales La Salle, 57 (147), 53-65.

Lujan, N.K., Meza-Vargas, V. \& Barriga-Salazar, R. (2015a) Two new Chaetostoma Group (Loricariidae: Hypostominae) sister genera from opposite sides of the Andes mountains in Ecuador, with the description of one new species. Copeia, 103 (3), $651-663$. https://doi.org/10.1643/CI-15-246

Lujan, N.K., Armbruster, J.W., Lovejoy, N. \& López-Fernández, H. (2015b) Multilocus molecular phylogeny of the suckermouth armored catfishes (Siluriformes, Loricariidae) with a focus on subfamily Hypostominae. Molecular Phylogenetics and Evolution, 62, 269-288. https://doi.org/10.1016/j.ympev.2014.08.020

Lujan, N.K., Meza-Vargas, V., Astudillo-Clavijo, V., Barriga-Salazar, R. \& López-Fernández, H. (2015c) A multilocus molecular phylogeny for Chaetostoma clade genera and species with a review of Chaetostoma (Siluriformes: Loricariidae) from the Central Andes. Copeia, 103 (3), 664-701. https://doi.org/10.1643/CI-14-194

Meek, S.E. \& Hildebrand, S.F. (1916) The fishes of the freshwaters of Panama. Field Museum of Natural History, Publications, Zoological Series, 10 (15), 1-374, pls. 6-32.

Pérez, A. \& Provenzano R., F. (1996) Cordylancistrus perijae, a new species of armored catfish (Siluroidei, Loricariidae) from the Maracaibo Basin, Venezuela. Studies on Neotropical Fauna and Environment, 31 (1), 27-34. https://doi.org/10.1076/snfe.31.1.27.13317

Provenzano, F. \& Milani, N. (2006) Cordylancistrus nephelion (Siluriformes, Loricariidae), a new and endangered species of armored suckermouth catfish from the Tuy River, north-central Venezuela. Zootaxa, 1116, 29-41.

Provenzano, F. \& Villa-Navarro, F.A. (2017) A new species of catfish genus Cordylancistrus (Siluriformes, Loricariidae) from Magdalena River, Tolima, Colombia. Zootaxa, 4292 (5), 522-530. https://doi.org/10.11646/zootaxa.4294.5.2

Rapp Py-Daniel, L.H. (1991) Chaetostoma jegui, a new mailed catfish from Rio Uraricoera, Brazil (Osteichthyes: Loricariidae). Ichthyological Exploration of Freshwaters, 2 (3), 239-246.

Sabaj, M.H. (2016) Standard symbolic codes for institutional resource collections in herpetology and ichthyology: an Online Reference. Version 6.5 (16 August 2016). American Society of Ichthyologists and Herpetologists, Washington, DC.Electronically accessible. Available from: http://www.asih.org/ (accessed 8 August 2017)

Salcedo, N.J. (2003) Análisis Filogenético del género Chaetostoma Tschudi, 1845 (Siluriformes: Loricariidae), con énfasis en especies Peruanas. Unpublished Master's Thesis. Universidad Nacional Mayor de San Marcos, Lima, 150 pp.

Salcedo, N.J. (2006a) New species of Chaetostoma (Siluriformes: Loricariidae) from Central Peru. Copeia, 1, 60-67. https://doi.org/10.1643/0045-8511(2006)006[0060:NSOCSL]2.0.CO;2

Salcedo, N.J. (2006b) Two new species of Chaetostoma (Siluriformes: Loricariidae) from the Huallaga River in central Peru. Ichthyological Exploration of Freshwaters, 17 (3), 207-220.

Salcedo, N.J. (2013) Description of Loraxichthys lexa, new genus and species (Siluriformes: Loricariidae) from the Rio Huallaga Basin, central Peru, with notes on the morphology of the enigmatic Lipopterichthys carrion Norman, 1935. Zootaxa, 3640 (4), $557-571$. https://doi.org/10.11646/zootaxa.3640.4.4

Salcedo, N.J. \& Ortega, H. (2015) A new species of Chaetostoma, an armored catfish (Siluriformes: Loricariidae), from the río Marañón drainage, Amazon basin, Peru. Neotropical Ichthyology, 13 (1), 151-156. https://doi.org/10.1590/1982-0224-20140073

Schultz, L.P. (1944) The catfishes of Venezuela, with descriptions of thirty-eight new forms. Proceedings of the United States National Museum, 94 (3172), 173-338, pls. 1-14.

Tan, M. \& Armbruster, J.W. (2012) Cordylancistrus santarosensis (Siluriformes, Loricariidae), a new species with unique snout deplatation from the Río Santa Rosa, Ecuador. Zootaxa, 3243, 52-58.

Tschanz, C., Marvin, R., Cruz, J., Mennert, H. \& Cebula, E. (1974) Geologic evolution of the Sierra Nevada de Santa Marta. Geological Society of America Bulletin, 85, 269-276. https://doi.org/10.1130/0016-7606(1974)85\%3C273:GEOTSN\%3E2.0.CO;2

Villamil, T. (1999) Campanian-Miocene tectonostratigraphy, depocenter evolution and basin development of Colombia and western Venezuela. Palaeogeography, Palaeoclimatology, Palaeoecology, 153, 239-275. https://doi.org/10.1016/S0031-0182(99)00075-9 